\title{
PENGARUH PENDIDIKAN KESEHATAN GIZI SEIMBANG \\ TERHADAP TINGKAT PENGETAHUAN IBU DENGAN BALITA USIA 6-24 \\ BULAN DI WILAYAH KERJA PUSKESMAS KARYA MULYA KOTA \\ PONTIANAK \\ THE EFFECT OF BALANCED NUTRITION HEALTH EDUCATION ON MOTHER KNOWLEDGE WITH THE AGE OF 6-24 MONTHS IN THE WORKING AREA OF KARYA MULYA HEALTH CENTER PONTIANAK CITY
}

\author{
Yuvita Anggraini*, Faisal Kholid Fahdi**, Ikbal Fradianto*** \\ *Mahasiswi Prodi Keperawatan Fakultas Kedokteran Universitas Tanjungpura, Pontianak \\ yuvitaanggraini03@gmail.com ** Dosen Keperawatan Fakultas Kedokteran Universitas Tanjungpura, \\ Pontianak faisal.psikuntan@ gmail.com *** Dosen Keperawatan Fakultas Kedokteran Universitas \\ Tanjungpura, Pontianak ikbal.fradianto@ners.untan.ac.id
}

\begin{abstract}
ABSTRAK
Latar Belakang: Faktor yang mempengaruhi pertumbuhan dan perkembangan balita menjadi baik adalah makanan yang dikonsumsi. Apabila makanan yang dikonsumsi seimbang, maka status gizi balita pun akan baik. Untuk itu, peran ibu sangat diperlukan dalam memenuhi kebutuhan makanan pada balita. Salah satu faktor yang mempengaruhi status gizi balita adalah pengetahuan.
\end{abstract}

Tujuan: Mengetahui Pengaruh pendidikan kesehatan gizi seimbang terhadap tingkat pengetahuan ibu dengan balita usia 6-24 bulan Wilayah Kerja Puskesmas Karya Mulya.

Metode: Penelitian kuantitatif quasi eksperimen pre and post test without control dengan metode purposive sampling. Responden pada penelitian ini sebanyak 73 responden. Analisis statistik menggunakan uji wilcoxon.

Hasil: Usia terbanyak ibu yaitu 26-35 tahun sebesar 37\% dengan tingkat pendidikan terbanyak SMA sebanyak 51 sebesar $69.9 \%$, jumlah pekerjaan terbesar adalah ibu rumah tangga sebanyak 60 orang sebesar $82,2 \%$, pengalaman ibu yang mempunyai 1 anak 33 orang sebesar $45,2 \%$. Hasil analisis uji wilcoxon menunjukan nilai $p=0,00$ yang berati $p<0,05$.

Kesimpulan: Ada pengaruh pendidikan kesehatan gizi seimbang terhadap tingkat pengetahuan ibu pada anak usia 6-24 bulan di Wilayah Kerja Puskesmas Karya Mulya

Kata Kunci: pendidikan kesehatan, gizi seimbang, pengetahuan 


\section{ABSTRACT}

Background: factors that influence the growth and development of toddlers to be good are foods consumed. If the food consumed is balanced, then the nutritional status of the toddler will be good. For this reason, the role of mothers is very necessary in fulfilling the food needs of infants. One of the factors that influence toddlers nutritional status is knowledge.

Objective: to know the effect of balanced nutrition health education on the level of knowledge of mothers with infants aged 6-24 months Working Area of Karya Mulya Health Center.

Method: Quantitative quasi-experimental research pre and post test without control using purposive sampling method. Respondents in this study were 73 respondents. Statistical analysis using the Wilcoxon test.

Results: The highest number of ages was 26-35 years old with $37 \%$ with the highest level of education at 51 as much as $69.9 \%$, the largest number of jobs were housewives as many as 60 people at $82.2 \%$, experiences of mothers who had 1 child 33 people amounting to $45,2 \%$. The results of the Wilcoxon test showed a value of $p=0.00$ which means $p<0.05$.

Conclusion: There is an influence of balanced nutrition health education on the level of knowledge of mothers in children aged 6-24 months in the Work Area of Karya Mulya Health Center

Key Word: Health Education, Balance Nutrition, Knowledge

\section{PENDAHULUAN}

Usia bayi berusia 6 bulan ibu akan mulai memberikan makan tambahan untuk bayinya. Syarat makanan yang seharusnya diberikan untuk balita adalah makanan yang memiliki protein yang tinggi, vitamin, dan mineral dalam jumlah cukup, dan terbuat dari bahan yang alami, serta mengandung $360 \mathrm{kkal}$ per $100 \mathrm{~g} .{ }^{1}$ Peneliti menemukan bahwa banyak ibu yang memberikan makanan tambahan untuk balitanya hanya dengan makan bubur nasi saja, sedangkan bubur nasi tersebut hanya mengandung karbohidrat. Peneliti juga menemukan bahwa ibu biasanya memberikan makanan yang enak kepada anaknya, tanpa tahu apakah makanan tersebut mengandung gizi-gizi yang cukup serta tidak mengimbanginnya dengan makanan sehat yang mengandung banyak gizi. ${ }^{2} \mathrm{Hal}$ tersebut sangat jauh dari syarat makanan yang seharusnya diberikan ibu untuk balitanya, jika keadaan ini berlangsungg terus menerus maka menyebabkan gizi balitanya tidak seimbang. Gizi yang tidak seimbang menyebabkan berbagai masalah gizi pada balita. ${ }^{3}$

Kasus gizi di Dunia masih menjadi masalah yang belum juga terselesaikan, berdasarkan data WHO (2018), terdapat 150,8 juta anak-anak yang usianya dibawah 5 tahun menderita stunting, 50,5 juta anak-anak usia dibawah 5 tahun juga menderita wasting, serta 38,3 juta anakdibawah 5 tahun menderita overweight. Benua yang menempati urutan 
pertama penderita gizi di dunia adalah asia dengan 83,6 juta anak menderita stunting, 35,0 juta anak menderita wasting, dan 17,5 juta anak menderita overweight. Di Benua Asia sendiri Asia Selatan menempati urutan pertama penderita gizi buruk paling banyak yaitu mencapai $33,3 \%$, lalu urutan kedua ditempati oleh Asia Tenggara yaitu mencapai $25,7 \%$, dan yang ketiga ditempati oleh Asia Barat yaitu mencapai $15,5 \%$.

Tahun 2017 Nusa Tenggara Timur (NTT) merupakan provinsi tertinggi dengan kasus gizi kurang sebesar $16 \%$, setelah NTT ada Kalimantan Barat dan Aceh dengan persentase $15,7 \%$ anak balita usia 0-23 bulan pada tahun 2017 mengalami gizi kurang (Kementrian Kesehatan RI, 2018). Data dinas kesehatan Provinsi Kalimantan Barat Pada tahun 2018, ada 401 kasus gizi buruk. Untuk penyebaran gizi buruk di kabupaten yang ada di Kalimantan Barat, kasus gizi buruk paling banyak ada di Kabupaten Kapuas Hulu, Kabupaten Ketapang, Kabupaten Mempawah, Kabupaten Sanggau dan di ikuti oleh Kota Pontinak, di Kabupaten Kapuas Hulu terdapat 89 kasus gizi buruk, Kabupaten Ketapang 55 kasus, Kabupaten Mempawah 50 kasus, Kabupaten Sanggau 48 kasus dan Kota Pontianak 41 Kasus.

Suatu wilayah dikatakan mengalami masalah gizi akut bila prevalensi balita pendek kurang dari $20 \%$ dan prevalensi balita kurus lebih dari $5 \% .^{5}$
Di Kalimantan Barat sendiri persentase balita sangat kurus $6,1 \%$ dan $10,3 \%$ balita kurus, serta $10,9 \%$ balita sangat pendek, balita pendek $17,4 \%$ hal tersebut menunjukkan karakteristik masalah gizi di Kalimantan barat dalam kategorik akut-kronis. Kota pontianak sendiri karakteristik masalah gizi nya termasuk dalam kategori Akut Kronis. Di Kota Pontianak $21,8 \%$ terdapat balita Underweight, 28,4\% balita balita di Kota Pontianak mengalami Stunting, dan 11,3\% balita di Kota Pontianak mengalami wasting. Dalam kategori masalah gizi di beberapa puskesmas di Kota Pontianak yaitu Puskesmas Karya Mulya termasuk dalam kategori kronis di peringkat pertama, yang di dalamnya terdapat $4,96 \%$ balita kurus, peringkat kedua adalah Puskesmas Tambelan sampit dengan persentase 3,98\%, peringkat ketiga Puskesmas Pal 5 dengan persentase 3,88\%, Peringkat keempat Puskesmas Saigon dengan persentase 3,42\%, peringkat kelima Puskesmas Parit Mayor dengan persentase 3,37 dan yang keenam Puskesmas Perumnas 2 dengan persentase 2,88 .

Gizi buruk merupakan salah
satu masalah yang yang
mengakibatkan $54 \%$ kematian
pada bayi dan anak (WHO, 2012).
Hasil data WHO tahun $201249 \%$
dari 10,4 juta kematian di Negara
berkembang berhubungan dengan
gizi buruk. Ada beberapa
klasifikasi dari gizi buruk yaitu
stunting (anak yang kerdil), kurus,
kegemukan, anemia wanita usia
produktif, berat badan lahir


rendah, pemberian asi ekslusif, dan berat badan dibawah normal. ${ }^{5}$

$$
\text { Status gizi seseorang }
$$

dipengaruhi oleh konsumsi makanan. Status gizi baik atau status gizi optimal terjadi bila tubuh memeroleh cukup zat-zat gizi yang digunakan secara efisien, sehingga memungkinkan pertumbuhan fisik, perkembangan otak, kemampuan kerja, dan kesehatan secara umum pada tingkat setinggi mungkin. Kekurangan zat-zat gizi esensial pada tubuh akan menyebabkan status gizi seseorang kurang/ buruk. $^{6}$

Berdasarkan data United Nations International Children's Emergency Fund (UNICEF) tahun 2012 ditemukan 1 dari 23 anak di Indonesia meninggal sebelum usia 5 tahun dan 1 dari 3 anak balita mengalami gizi buruk yang menyebabkan terhambatnya pertumbuhan balita tersebut. ${ }^{7}$ Gizi buruk tidak ditangani maka akan menimbulkan beberapa dampak di berbagai aspek, yaitu dapat menurunkan imunitas balita, menimbulkan kecacatan, angka kesakitan dan kematian balita tinggi. ${ }^{8}$ Mencegah terjadinya gizi buruk maka harus dilakukan pemenuhan gizi seimbang berdasarkan prinsip piramida gizi seimbang yang diatur dalam Undang-Undang Kesehatan No 36 Tahun 2009 yang di Indonesia dikenal dengan tumpeng gizi seimbang. Sedangkan saat ini banyak masyarakat terutama ibuibu yang masih menggunakan prinsip 4 sehat 5 sempurna, padahal prinsip 4 sehat 5 sempurna sudah sejak tahun 1990- an telah diganti dengan piramida gizi seimbang dikarenakan susu bukan lagi merupakan makanan sempurna. $^{9}$

Penelitian

Suzanna,

Budiastutik \& Marlenywati (2017) Salah satu faktor yang mempengaruhi pertumbuhan dan perkembangan balita menjadi baik adalah makanan yang dikonsumsi. Apabila makanan yang dikonsumsi seimbang, maka status gizi balita pun akan baik. Untuk itu, peran ibu sangat diperlukan dalam memenuhi kebutuhan makanan pada balita. Salah satu faktor yang mempengaruhi status gizi balita adalah pengetahuan orangtua terutama ibu.

Penelitian In'Am (2016) terdapat hubungan yang signifikan antara tingkat pengetahuan orangtua dengan status gizi anak dibawah 5 tahun di Posyandu Wilayah Kerja Puskesmas Nussukan Surakarta, hal ini juga didukung dengan penelitian yang dilakukan oleh Tantejo, Chriastianto, \& Restuastuti (2014) yang hasilnya terdapat hubungan antara pengetahuan ibu tentang gizi dengan status gizi balita di Wilayah Kerja Puskesmas XIII Kota Kampar Tahun 2013. Serta berdasarkan hasil penelitian yang dilakukan Oleh Puspitasari \& Andriani (2017) yang hasilnya terdapat hubungan pengetahuan ibu tetang gizi dan asupan makan balita dengan status gizi balita usia 12-24 bulan. Hasil penelitian Pratiwi tahun 2017 pengetahuan dapat ditingkatkan dengan cara memberikan

pendidikan 
kesehatan, salah satu media yang dapat digunakan dalam memberikan pendidikan kesehatan adalah media booklet. Hasil penelitian-penelitan tersebut dijelaskan bahwa untuk mengatasi kurangnya pengetahuan ibu diperlukannya peningkatan pengetahuan ibu tentang gizi melalui pendidikan kesehatan gizi seimbang. Peneliti memberikan pendidikan kesehatan tentang gizi seimbang terhadap ibu yang memiliki balita usia 6-24 bulan di Wilayah Kerja Puskesmas Karya Mulya (Pratiwi, 2017)

\section{METODE}

Jenis penelitian ini adalah penelitian kuantitatif quasi eksperimen pre and post test without control. Populasi dalam penelitian ini adalah ibu yang mempunyai balita usia 6-24 bulan yang terdata dan berada di wilayah kerja Puskesmas Karya Mulya Kota Pontianak yang berjumlah 90 orang. Peneliti menggunakan teknik purposive sampling dan menggunakan rumus slovin sehingga didapatkan sampel 73 responden.

Variabel independen pada penelitian ini adalah Pendidikan Kesehatan Gizi Seimbang, variabel dependen penelitian ini adalah tingkat pengetahuan ibu dengan balita usia 6-24 bulan. Data pada penelitian ini dikumpulkan dengan lembar observasi dan kuesioner tingkat pengetahuan ibu yang telah diuji validitas dan reabilitas. Data dianalisis secara univariat dengan distribusi frekuensi dan bivariat dengan uji wilcoxon.

\section{HASIL PENELITIAN}

Tabel 1 Karakteristik Responden Penelitian Pendidikan Kesehatan Gizi Seimbang Terhadap Tingkat Pengetahuan Ibu dengan Balita Usia 624 Bulan di Wilayah Kerja Puskesmas Karya Mulya Kota Pontianak

\begin{tabular}{|c|c|c|}
\hline Karakteristik & $f$ & $\%$ \\
\hline \multicolumn{3}{|l|}{ Usia } \\
\hline$<25$ Tahun & 27 & 37 \\
\hline 26-35 Tahun & 38 & 52 \\
\hline 36-45 Tahun & 8 & 11 \\
\hline >46Tahun & 0 & 0 \\
\hline
\end{tabular}

\begin{tabular}{lcc}
\hline Pekerjaan & 3 & 4.1 \\
PNS & 4 & 5.5 \\
Wiraswasta & 4 & 5.5 \\
Pegawai Swasta & 60 & 82.1 \\
Ibu Rumah Tangga & 1 & 1.4 \\
Petani/Buruh & 1 & 1.4 \\
PRT & & \\
Pendidikan & 1 & 1.4 \\
Tidak Sekolah & 2 & 2.7 \\
SD & 10 & 13.7 \\
SMP & 51 & 69.9 \\
SMA & 9 & 12.3 \\
Perguruan Tinggi & & \\
& & \\
Pengalaman & 33 & 45.2 \\
1 & 27 & 37.0 \\
2 & 8 & 11 \\
3 & 1 & 1.4 \\
4 & 2 & 2.7 \\
5 & 2 & 2.7 \\
\hline Lain-lain &
\end{tabular}

Menunjukkan bahwa kategori usia responden sebgaian besar pada usia 26-35 tahun sebanyak 38 dengan persentase $52 \%$. Kategori pekerjaan responden sebagian besar ibu rumah tangga sebanyak 60 responden dengan persentase $82.2 \%$. Kategori pendidikan responden sebagian besar berpendidikan sekolah menengah atas sejumlah 51 responden, dengan persentase 
69,9\%, jumlah anak responden sebagian besar 1 sejumlah 33 responden dengaan persentase $45.2 \%$.

Tabel 2 Pengetahuan Ibu Sebelum diberikan Pendidikan Kesehatan Gizi Seimbang di Wilayah Kerja Puskesmas Karya Mulya Kota Pontianak

\begin{tabular}{lcc}
\hline Tingkat & \multicolumn{2}{c}{ Sebelum } \\
\cline { 2 - 3 } $\begin{array}{l}\text { Pengetahua } \\
\text { n Ibu }\end{array}$ & $\boldsymbol{F}$ & $\boldsymbol{\%}$ \\
\hline $0-6$ & 33 & 45.2 \\
$7-14$ & 40 & 54.8 \\
\hline
\end{tabular}

Berdasarkan tabel 4.2 Karakteristik tingkat pengetahuan sebelum diberian pendidikan kesehatan menunjukkan 33 responden pengetahuannya dalam rentang 0 6 sebesar $45.2 \%$, dan 40 responden dengan $54.8 \%$ pengetahuan responden dalam rentang 7-14.

Tabel 3 Pengetahuan Ibu Sesudah diberikan Pendidikan Kesehatan Gizi Seimbang di Wilayah Kerja Puskesmas Karya Mulya Kota Pontianak

\begin{tabular}{lcc}
\hline Tingkat & \multicolumn{2}{c}{ Sesudah } \\
\cline { 2 - 3 } $\begin{array}{l}\text { Pengetahuan } \\
\text { Ibu }\end{array}$ & $\boldsymbol{F}$ & $\%$ \\
\hline $0-6$ & 0 & 0 \\
$7-14$ & 73 & 100 \\
\hline
\end{tabular}

Berdasarkan tabel 3 Karakteristik tingkat pengetahuan sesudah diberikan pendidikan kesehatan $100 \%$ menunjukkan tingkat pengetahuan responden dalam rentang 7-14.
Tabel 4 Pengaruh Pendidikan Kesehatan Gizi Seimbang Terhadap Tingkat Pengetahuan Ibu dengan Balita Usia 6-24 Bulan di Wilayah Kerja Puskesmas Karya Mulya

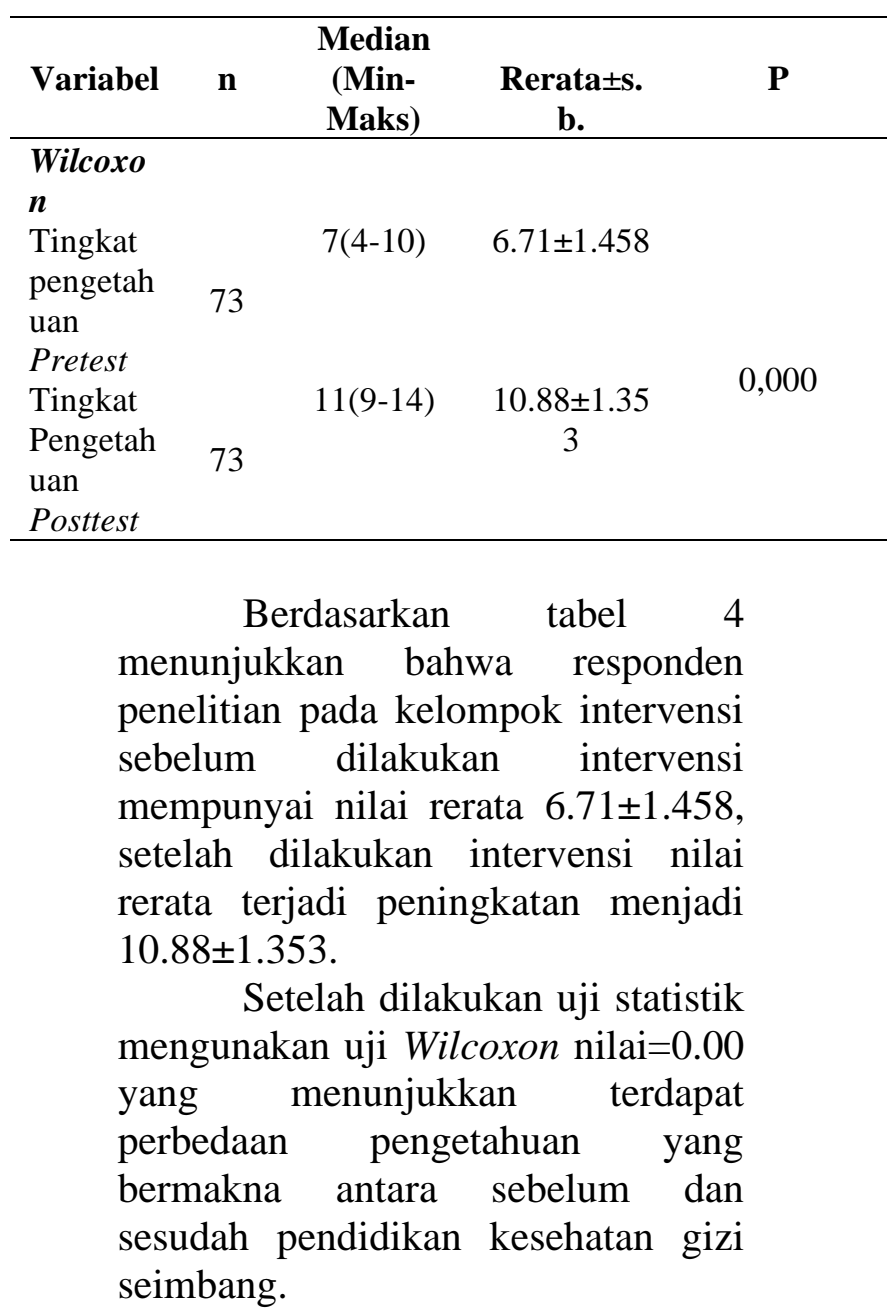

PEMBAHASAN

Karakteristik Ibu Yang Mempunyai Anak Usia 6-24 Bulan di Puskesmas Karya Mulya

Mayoritas responden berusia 26-35 tahun dimana usia merupakan salah satu faktor yang mempenggaruhi pengetahuan selain pendidikan, pekerjaan dan pengalaman. ${ }^{10}$

Seiring bertambahnya usia seseorang maka akan terjadi 
perubahan pada aspek fisik dan psikologis. ${ }^{11}$ Usia 26-35 tahun adalah usia yang paling baik untuk membesarkan anak, karena kesehatannya optimal dengan harapan hidup yang cukup dan memadai untuk membangun sebuah keluarga serta dapat menjalankan peran pengasuhan yang optimal diperlukannya kekuatan fisik dan psikologis. ${ }^{12}$

Mayoritas pendidikan

responden adalah SMA yang dianggap sebagai tingkat pendidikan menengah atas, sehingga semakin mudah pula mereka menerima informasi yang diberikan. ${ }^{13}$ Menurut Suwanti \& Wahyuni (2012) ada hubungan yang signifikan antara pendidikan dan pengetahuan, karena pendidikan seseorang mempengaruhi sikap atau respon yang diberikan terhadap informasi yang ia peroleh. Ibu harus memiliki pendidikan yang baik agar dapat menjalankan fungsinya dengan efektif sehingga akan mendatangkan perilaku kesehatan yang baik pula. Sebagian besar responden menjadi ibu rumah tangga, sehingga akses untuk mendapatkan informasi lebih kecil dibandingkan ibu yang bekerja diluar rumah. $^{14}$ Lingkungan perkerjaan dapat menjadikan seseorang memperoleh pengalaman dan pengetahuan baik secara baik secara langsung maupun tidak langsung. Seorang ibu rumah tangga yang sehari-harinya terbiasa menyiapkan makanan bagi anggota keluarganya haruslah mempunyai pengetahuan tentang gizi seimbang sehingga dapaat meningkatkan serta meempertahankan derajat kesehatan anggota keluarganya. ${ }^{15}$ Semakin banyak pekerjaan ibu sebagai ibu rumah tangga, maka ibu semakin banyak waktu untuk mengasuh dan merawat anaknya sehingga pemenuhan gizi anak terpantau dan tercukupi.

Pengetahuan adalah suatu hal yang berasal dari pancaindra dan pengalaman. ${ }^{16} \quad$ Pengalaman merupakan salah satu faktor yang mempengaruhi pengetahuan dengan cara mengulang kembali pengalaman yang diperoleh dalam memecahkan permasalahan yang dihadapi pada masa yang lalu. ${ }^{17}$ Seiring pertambahan usia maka pengalaman dan kematangan jiwa akan semakin meningkat. Ibu yang mempunyai anak lebih dari satu cenderung pengetahuannya lebih tinggi dikarenakan pengalamannya yang sudah pernah mengasuh anaknya dan mempunyai informasi yang lebih luas ..$^{18}$

Pengetahuan Ibu Sebelum Diberikan Pendidikan Kesehatan Gizi Seimbang di Wilayah Kerja Puskesmas Karya Mulya

Sebelum dilakukan pendidikan kesehatan sebagian besar pengetahuan ibu sudah baik yang dipengaruhi oleh faktor usia, pendidikan, pekerjaan dan pengalaman, tetapi ada beberapa item pertanyaan yang rata-rata jawaban responden salah hal ini menunjukkan bahwa ibu belum tahu secara mendalam mengenai gizi seimbang. ${ }^{10}$ Tingkat pendidikan ibu sebagian besar SMA, tingkat pendidikan tersebut termasuk dalam kategori baik, dimana tingkat pendidikan baik tersebut akan mempengaruhi pengetahuan seseorang menjadi baik juga. ${ }^{19}$

Faktor lain dari pengetahuan adalah usia ibu yang mana rata-rata usia ibu 
26-35 dimana usia tersebut ibu dalam kelompok usia yang memiliki kematangan dalam hal rasional maupun motoric. ${ }^{20}$ Menurut penelitian yang dilakukan oleh Rahmawati, Dasuki, \& Candrasari, (2016) usia 26-35 tahun merupakan usia produktif sehingga mudah untuk menerima informasi yang baru yang berhubungan dengan kesehatan anaknya.

\section{Pengetahuan Ibu Sesudah Diberikan Pendidikan Kesehatan Gizi Seimbang di Wilayah Kerja Puskesmas Karya Mulya}

Berdasarkan hasil jawaban reponden dalam kuesioner dapat dikatakan reponden memahami pendidikan kesehatan yang diberikan oleh peneliti, hal ini dikarenakan setelah diberikan pendidikan kesehatan gizi seimbang pengetahuan ibu meningkat. $^{21}$

Peningkatan pengetahuan disebabkan oleh faktor penyuluh yaitu persiapan yang matang, materi mengusai materi, bahasa yang digunakan dan kepercayaan sasaran kepada pemateri. ${ }^{22}$ Peningkatan pengetahuan juga berhubungan dengan minat, semakin tinggi minat seseorang terhadap suatu hal, maka semakin tinggi pula tingkat pengetahuannya. ${ }^{23}$

\section{Pengaruh Pendidikan Kesehatan Gizi Seimbang Terhadap Tingkat Pengetahuan Ibu Dengan Balita Usia 6-24 Bulan}

Penelitian ini membuktikan bahwa pendidikan kesehatan gizi seimbang berpengaruh terhadap tingkat pengetahuan ibu, hal ini ditandai dengan peningkatan rerata yang awalnya 6,71 menjadi 10,88 dan serupa dengan penelitian yang dilakukan oleh Azria \& Husnah (2016) dan Zulaekah (2012). Peningkatan pengetahuan ini disebabkan karena faktor pendidikan, pendidikan kesehatan merupakan salah satu upaya pemecahan masalah kesehatan melalui pendidikan. Pendidikan kesehatan sangat penting karena akan menunjang programprogram kesehatan lainnya. ${ }^{24}$

Melalui pendidikan kesehatan informasi-informasi penting akan sampai kepada klien sehingga pengetahuannya meningkat. Pengetahuan seserang dapat mempengaruhi pola pikir ke arah yang positif sehingga akan menumbuhkaan perilaku atau kebiaasaan hidup sehat. ${ }^{25}$ Media merupakan salah satu faktor penting dalam penerimaan informasi seseorang. Salah satu media yang dapat digunakan adalah booklet yang berisi panduan gizi seimbang untuk balita usia 6-24 bulan. Proses membaca akan menghasilkan pengetahuan, proses yang masuk dalam otak manusia yaitu $10 \%$ proses dari hal-hal yang didengar dan dilihat serta $50 \%$ dari yang dilihat dan didengar, sehingga seseorang mudah untuk memahami pengetahuan yang didapat pada saat diberikan pendidikan kesehatan menggunakan media. ${ }^{26}$

Media merupakan sarana untuk menampilkan pesan yang akan disampaikan oleh pemateri, sehingga membuat sasaran lebih memahami apa yang ingin disampaikan oleh pemateri. ${ }^{26}$ Media booklet merupakan salah satu media yang dapat membuat seseorang memahami isi materi yang diberikan karena materinya lebih terperinci dan jelas 
serta menampilkan lebih banyak informasi dibandingkan media cetak yang lain seperti poster, atau leaflet. ${ }^{27}$

Pengetahuan merupakan hal yang sangat penting dalam membentuk tindakan seseorang, terutama ibu jika pengetahuan ibu gizi seimbang ibu baik maka perilaku pemenuhan gizi balitanya juga baik. ${ }^{28}$ Hal ini didukung oleh penelitian yang dilakukan oleh Farhan, (2014) yang menyatakan bahwa ada hubungan yang bermakna antara pengetahuan ibu rumah tangga tentang gizi seimbang dengan perilaku pemenuhan gizi pada balita. Jika perilaku pemenuhan gizi balita baik maka akan mengurangi kekurangan gizi dan penyakit infeksi pada balita. $^{29}$

\section{KESIMPULAN}

Karakteristik ibu yang mempunyai anak usia 6-24 bulan di Wilayah Kerja Puskesmas Karya Mulya pada usia 26-35 tahun dengan persentase $52.1 \%$, karakteristik pekerjaan ibu adalah ibu rumah tangga dengan persentase $82.2 \%$, karakteristik pendidikan ibu adalah SMA dengan persentase $69.9 \%$, dan karakteristik pengalaman ibu mempunyai anak 1 persentasenya $45.2 \%$. Karakteristik tingkat pengetahuan ibu dengan anak usia 624 bulan di Wilayah Kerja Puskesmas Karya Mulya sebelum dilakukan pendidikan kesehatan gizi seimbang sebagian besar memiliki rentang 7-14 dengan persentase 54.8\%.Karakteristik tingkat pengetahuan ibu dengan anak usia 624 bulan di Wilayah Kerja Puskesmas Karya Mulya setelah dilakukan pendidikan kesehatan gizi seimbang $100 \%$ skor pengetahuannya dalam rentang 7-14. Terdapat pengaruh pendidikan kesehatan gizi seimbang terhadap tingkat pengetahuan ibu pada balita usia 6-24 bulan di Wilayah Kerja Puskesmas Karya Mulya.

\section{DAFTAR PUSTAKA}

1. Sudaryanto, G. (2017). 200 Makanan Sehat Bayi dan Balita. Jakarta: Penebar Plus.

2. Sitorus, R. H. (2011). Pedoman Perawatan Balita. Bandung: Nuansa Aulia.

3. Lestari, T. W., Hartati, L. E., \& Budiyati. (2014). Pengaruh Pemberian Makan Balita dan Pengetahuan Ibu Terhadap Status Gizi Balita Di Kelurahan Meteseh Kecamatan Tembalang Kota Semarang. 310-319.

4. Kementerian Kesehatan RI. (2017). Buku Saku Pemantauan Status Gizi Tahun 2017. Jakarta: Kementerian Kesehatan RI.

5. WHO. (2012, 7 5). Levels \& Trends In Child Malnutrition. pp. 1-35.

6. Almatsier, S., Soetardjo, S., \& Soekatri, M. (2011). Gizi Seimbang Dalam Daur Kehidupan. jakarta: Gramedia.

7. UNICEF, WHO,WORDL BANK GROUP. (2018). Level And Trends In Child Malnutrition. Washington: Joint Child Malnutrition Estimates.

8. Rahim, F. K. (2014). Faktor Risiko Underweight Balita Umur 7-59 Bulan. Jurnal 
Kesehatan Masyarakat, 115121.

9. Kementrian Kesehatan RI. (2014). Pedoman Gizi Seimbang. Jakarta: Kementerian Kesehatan RI.

10. Mubarak, W. I. (2011). Promosi Kesehatan Untuk Kebidanan. Jakarta: Salemba Medika.

11. Suwanti, E., \& Wahyuni, S. (2012). Karakteristik Ibu Kaitannya Pengetaahuan Ibu Tentang Posyandu. Jurnal Terpadu Ilmu Kesehatan, 194.

12. Salafiah, N., Widodo, A., \& Suryandari, D. (2014). Pengaruh Pendidikan Kesehatan Terhadap Pengetahuan Dan Sikap Ibu Tentang Pola Asuh Anak Usia Bayi (INFANT) di Wilayah Kerja Puskesmas Kartasura. Jurnal UMS, 1-16.

13. Pamarta, D. (2018). Pengaruh Faktor Predisposisi (Usia, Pendidikan, Pekerjaan, Pengetahuan, SIkap) Ibu Terhadap Ketetapan Pemberian Makanan Pendamping Air Susu Ibu (MPASI) Di Desa Kenep Kecamatan Sukoharjo Kabupaten Sukoharjo. Jurnal UMS, 1-14.

14. Novita, M. R., Ambarwati, W. N., \& Listyorini, D. (2013). Pengaruh Pendidikan Kesehatan Terhadap Pengetahuan Ibu Tentang Kandungan Air Susu Ibu Di Desa Kaliwuluh Kebakkramat Karangayar. Jurnal UMS, 1-13.
15. Azria, C. R., \& Husnah. (2016). Pengaruh Penyuluhan Gizi Terhaadap Pengetahuan dan Perilaku Ibu Tentang Gizi Seimbang Balita Kota Banda Aceh. Jurnal Unsyiah, 87-92.

16. Lestari , T. (2015). Kumpulan Teori Untuk Kajian Pustaka Penelitian Kesehatan. Yogyakarta: Nuha Medika.

17. Suryaningsih, C. (2013). Pengaruh Pendidikan Kesehatan Terhadap Pengetahuan Ibu Post Partum Tentang ASI Eklusif. Jurnal Keperawatan Soedirman, 7786.

18. Suriyana, Y. (2015). Metode Penelitian. Bandung: CV Pustaka Setia.

19. Ni'mah, C., \& Muniroh, L. (2016). Hubunan Tingkat Pendidikan, Tingkat Pengetahuan dan Pola Asuh Ibu dengan Wasting dan Stunting Pada Balita Keluarga Miskin. Jurnal Unair, 84-70.

20. Saputra, W. I., \& Irdawati. (2017). Hubungan Tingkat Pengetahuan Ibu dengan Tumbuh Kembang Bayi Prematur Usia 6-12 Bulan di Wilayah Kerja Puskesmas Se-Kecamatan Banjarsari. Jurnal UMS, 50-57.

21. Farhan, M. (2014). Hubungan Pengetahuan Ibu Rumah Tangga Tentang Gizi Seimbang Dengan Perilaku Pemenuhan Gizi Seimbang Pada Balita Usia 3-5 Tahun Di Dessa Banjarsari Kecamatan Ciawi Kabupaten Bogor. Skripsi. 
22. Sidiq, R. (2018). Efektivitas Penyuluhan Kesehatan

Dalam Meningkatkan Pengetahuan Kader Posyandu Tentang Pencegahan Pneumonia Pada Balita. Aceh Nutrrition Journal, 22-27.

23. Wardani, N. I., SR, D. S., \& Masfiah, S. (2014). FaktorFaktor Yang Berhubungan Dengan Tingkat Pengetahuan Kader Kesehatan Tentang Thalassaemia Di Kecamatan SUmbang Kabupaten Banyumas. Jurnal Kesmaindo, 194-206.

24. Notoatmodjo, S. (2011). Promosi Kesehatan dan Ilmu Perilaku. Jakarta: PT Rineka Cipta.

25. Pratiwi, Y. F. (2017). Efektivitas Penggunaan Media Booklet Terhadap Pengetahuan Gizi Seimbang Pada Ibu Balita Gizi Kurang Di Keluarahan Semanggu Kecamatan Pasar Kliwon kota Surakarta. Universitas Muhammadiyah Surakarta, 1-12.

26. Suiraoka, I. P., \& Supariasa, I. D. (2012). Media Pendidikan Kesehatan. Yogyakarta: Graha Ilmu.

27. Kusrianto, A. (2009). Pengantar Desain Komunikasi Visual. Yogyakarta: Andi.

28. Rahmawati, A. K., Dasuki, M. S., \& Candrasari, A. (2016). Hubungan Antara Pengetahuan Ibu Tentang Gizi Seimbang Dan Asupan Zat Gizi Makro Pada Anak Usia 2-5 Tahun Di Posyandu
Gonilan Kartasura. Jurnal UMS, 1-20.

29. In'Am , M. (2016). Hubungan Tingkat Pengetahuan Orangtua Dengan Status Gizi Anak Di Bawah 5 Tahun Di Posyandu Wilayah Kerja Puskesmas Nusukan Surakarta. Universitas Muhammadiyah Surakarta, 1-11. 